\title{
Cloning of Geranylgeranyl Pyrophosphate Synthase (CrtE) Gene from Kocuria gwangalliensis and Its Functional Co-expression in Escherichia coli
}

\author{
Yong Bae Seo ${ }^{1 \dagger}$, Gun-Do Kim ${ }^{1+}$ and Jae Hyung $\mathrm{Lee}^{2} \star$ \\ ${ }^{1}$ Department of Microbiology, College of Natural Sciences, Pukyong National University, Busan 608-737, Korea \\ ${ }^{2}$ Basic Science Research Institute, Pukyong National University, Busan 608-737, Korea
}

Received July 12, 2012 /Revised July 31, 2012 /Accepted August 7, 2012

\begin{abstract}
A gene encoding a novel geranylgeranyl pyrophosphate (GGPP) synthase from Kocuria gwangalliensis has been cloned and expressed in Escherichia coli. The deduced amino acid sequence showed 59.6\% identity with a putative GGPP synthase (CrtE) from $K$ rhizophila. An expression plasmid containing the $c r t E$ gene was constructed, and E. coli cells containing this plasmid produced a recombinant protein with a theoretical molecular mass of $41 \mathrm{kDa}$, corresponding to the molecular weight of GGPP synthase. Due to the lack of $c r t E, c r t B$, and $c r t I$ in $E$. coli, the biosynthesis of lycopene was only obtained when the plasmid pCcrtE was co-transformed into $E$. coli expressing the pRScrtBI-carrying carotenoid biosynthesis $c r t B$ and $c r t I$ genes, which were sub-cloned from Paracoccus haeundaensis. The biochemical studies on the expressed proteins were performed via HPLC. The results obtained from this study will provide a wider base of knowledge regarding the primary structure of CrtE cloned from $K$ gwangalliensis at the molecular level.
\end{abstract}

Key words : Kocuria gwangalliensis, carotenoid, geranylgeranyl pyrophosphate (GGPP), lycopene, geranylgeranyl pyrophosphate synthase (CrtE)

\section{서 론}

이소프레노이드(isoprenoid)는 자연계에 널리 존재하는 물 질로 이소프렌 $\left(\mathrm{C}_{5}\right)$ 단위가 반복적으로 구성된 생체분자이며, 현재까지 약 55,000 개 정도의 물질이 이소프레노이드 또는 테 르페노이드(terpenoid)로 알려져 있다[4,8]. 이러한 이소프레 노이드를 전구체로 하여 생산되는 생체 내 대사산물로는 카로 티노이드(carotenoid), 세포막 성분인 스테롤(sterol), 단백질 의 당화과정(glycosylation)에 첨가되는 돌리콜(dolichol), 전자 전달계의 유비퀴논(ubiquinone), 전사과정의 isopentenylated tRNA, 호르몬으로 앱시스산(abscisic acid), 시토카인 (cytokinins), 지베렐린(giberellic acid), 스테로이드 호르몬 등 이 있으며 이들은 신진대사와 세포의 구조에 매우 중요한 역 할을 한다[1,3].

이소프레노이드를 전구체로 하여 생산되는 다양한 생리활 성 물질군 중 카로티노이드 생합성 과정을 살펴보면 Fig. 1에 서와 같이 farnesyl pyrophosphate (FPP)와 isopentenyl pyrophosphate (IPP)가 축합되어 geranylgeranyl pyrophosphate (GGPP)가 생산된다. 이러한 GGPP 생합성에 관

\footnotetext{
*Corresponding author

Tel : +82-51-629-5618, Fax : +82-51-629-5619

E-mail : haehoo76@pknu.ac.kr

\# Yong Bae Seo and Gun-Do Kim are contributed equally for the work.

\# The GenBank accession number for the CrtE nucleotide sequence reported here is JN582050
}

여하는 geranylgeranyl pyrophosphate synthase (GGPP synthase; $\mathrm{CrtE}$ )는 prenyltransferase 그룹에 속하는 효소로 두 개 의 동일한 폴리펩티드로 이루어져 있으며, 이들 대부분은 전 구체를 mono-, sesqui-, diterpenoids로 만드는 역할을 하기 때문에 생체 내에서 테르페노이드 생합성의 중요한 분지점 효소로서 보고되고 있다[2,21]. GGPP synthase에 의해 합성된 GGPP는 생물체마다 서로 다른 역할을 다양하게 수행하고 있 으며, 진핵생물의 경우 prenylation된 단백질의 $\mathrm{C}_{20}$ 지질 일부 분을 합성하기 위한 필수적인 전구체이며, 식물과 다양한 미 생물의 경우는 카로티노이드 생합성에 있어서 필수적인 전구 체이다[11].

카로티노이드를 생합성하는 식물 및 미생물에서 이들이 생 산하는 첫번째 카로티노이드는 파이토엔(phytoene)이며, 이 는 두 분자의 $\mathrm{GGPP}$ 가 축합될 때 생성된다. 이처럼 $\mathrm{C}_{30}, \mathrm{C}_{40}$ 및 $\mathrm{C}_{50}$ 의 카로티노이드가 생체 내에서 생합성 되기 위해서는 카로티노이드 생합성 경로에서 GGPP가 반드시 필요한 기질 이 된다. 이러한 GGPP을 생합성하는 GGPP synthase는 $c r t E$ 에 의해 암호화 되어 있으며, 현재까지 세균에서 밝혀진 $c r t E$ 는 Kocuria rhizophila (accession no. NC010617) [20], Micrococcus luteus (accession no. ZP06502819) [23], Arthrobacter arilaitensis (accession no. YP003916548) [9], Clavibacter michiganensis (accession no. YP001711260) [22], Sanguibacter keddieii (accession no. YP003314051) [6], Paracoccus haeundaensis (accession no. AY957386) [12] 등에서 클로닝 되어 보고되었다.

본 연구에서는 Kocuria gwangalliensis [16]의 genomic DNA 
에서 GGPP 생합성에 관여하는 GGPP synthase를 암호화하는 $c t E$ 유전자를 클로닝하여 대장균에서 발현시킨 후, 본 저자에 의해 연구 및 보고된 P. haeundaensis의 카로티노이드 생합성 유전자 ( $c r t B$ 및 $c r t)$ 와 새롭게 분리된 $K$ gwangalliensis의 $c r t E$ 유전자를 이용하여 라이코펜 생합성을 유도하였다. 또한 이들 유전자에 의해 발현되는 효소들의 작용에 의해 생산된 라이코 펜을 HPLC을 이용하여 대장균에서 라이코펜 생산 유무를 검 증하였다. 이와 같은 연구 결과는 새로이 밝혀진 $K$ gwangalliensis가 생합성하는 카로티노이드의 조절 메커니즘을 이해하 고 비카로티노이드 생합성 균주에서 카로티노이드의 생산 및 생산증대 연구에 대한 기초 데이터를 제공할 것이다.

\section{재료 및 방법}

\section{균주 및 배양조건}

본 연구에 사용된 균주는 부산 광안리 연근해에서 분리·동 정된 핑크색 색소를 생성하는 $K$ gwangalliensis을 PPES-II [ 0.2 g Polypeptone, $1.0 \mathrm{~g}$ Bacto soytone, $1.0 \mathrm{~g}$ Proteose peptone, $1.0 \mathrm{~g}$ Bacto yeast extract, $3 \% \mathrm{NaCl}, 0.1 \%$ Ferric citrate, 1 distilled water (DW)] 배지에서 $25^{\circ} \mathrm{C}$ 교반 배양 하였으며, 형질전 환에 사용된 대장균 균주 XL1-blue [endA1 gyrA96 $\left(\mathrm{nal}^{\mathrm{R}}\right)$ thi-1 recA1 relA1 lac glnV44 $\mathrm{F}^{\prime}\left[\because \operatorname{Tn} 10\right.$ proAB $^{+}$lacl $^{\mathrm{q}} \Delta$ (lacZ) M15] hsdR17 ( $\left.\mathrm{rK}^{-} \mathrm{mK}^{+}\right)$]와 BL21 (DE3) [ $\mathrm{F}^{-} \mathrm{ompT}$ gal dcm lon hsdS $S_{B}\left(r_{B}^{-} m_{B}^{-}\right) \lambda$ (DE3 [lacI lacUV5-T7 gene 1 ind1 sam7 nin5]) ]는 Luria-Bertani (LB; 1\% Tryptone, $0.5 \%$ Yeast extract, $1 \% \mathrm{NaCl}$ ) 배지에서 $37^{\circ} \mathrm{C}$ 교반 배양하여 사용하였다.

\section{Genomic DNA 분리 및 Cosmid library구축}

K. gwangalliensis의 genomic DNA 분리는 AccuPrep Genomic DNA Extraction Kit (Bioneer, Korea)을 사용하여 추출하였으며, 그 과정은 다음과 같다. 멸균된 $1.5 \mathrm{ml}$ tube에 배양액 $1 \mathrm{ml}$ 을 넣고 $14,000 \mathrm{rpm}$ 에서 2분간 원심분리하여 침전 시킨 후 침전물을 취해 $200 \mu \mathrm{l}$ 의 lysis buffer와 $20 \mu \mathrm{l}$ 의 단백 질 분해효소 $\mathrm{K}$ (proteinase $\mathrm{K}$ )를 첨가 후, $56^{\circ} \mathrm{C}$ 에서 1 시간 반응시
켰다. 침전물이 완전히 분해되면 $200 \mu l$ 의 binding buffer를 넣고 $60^{\circ} \mathrm{C}$ 에서 10 분간 반응시킨 후 $100 \mu \mathrm{l}$ 의 이소프로파놀 (isopropanol)을 넣고 섞어준 후, binding column에 옮긴 다음 $8,000 \mathrm{rpm}$ 에서 1 분간 원심 분리 후, $500 \mu \mathrm{ll}$ 의 washing buffer을 넣고 $8,000 \mathrm{rpm}$ 에서 1 분간 원심분리 하였으며 이를 2 회 실시 하였다. 원심분리가 끝난 후 binding column을 $1.5 \mathrm{ml}$ 멸균 튜브에 옮겨 $100 \mu \mathrm{l}$ elution buffer을 넣고 5 분간 상온에서 반응 한 후 $8,000 \mathrm{rpm}$ 에서 1 분간 원심 분리하여 genomic DNA을 분리하였다. 또한, Cosmid genomic library 제작은 Sambrook 과 Russell의 방법[15]을 일부 변경하여 genomic library를 구 축하였다.

\section{GGPP synthase (cott) 클로닝 및 염기서열 결정}

$K$ gwangalliensis 의 cosmid genomic library로부터 GGPP synthase $(c t t)$ 유전자의 클로닝을 위하여 계통학적으로 유연 관계가 높은 균주들로부터 GGPP synthase의 보존된 영역을 NCBI (National Center for Biotechnology Information, USA) conserved domains site에서 검색하여 이를 기반으로 degenerate primer을 디자인 하였다(Table 1). Degenerate primer을 이용 $\mathrm{PCR}$ 을 수행하여 부분 단편을 증폭하였다. $c t E$ 유전자의 open reading frame (ORF)을 클로닝 하기 위하여 DNA walking speedup premix kit (Seegene, Seoul, Korea)을 이용하였 다. DNA walking kit을 이용하여 증폭된 유전자는 pGEM-T easy vector (Promega, Madison, WI, USA)에 각각 클로닝 하 였으며, 각 클론들의 DNA 염기서열을 분석하여 최종적으로 $c r t E$ 서열을 확보하였고, 이를 NCBI GeneBank에 등록하였다.

\section{K. gwangalliensis GGPP synthase (CrtE) 염기서열 분석}

K. gwangalliensis 유래 $\mathrm{CrtE}$ 효소의 1차 구조 및 염기서열 분석은 NCBI GeneBank database의 BLAST algorithm을 이용 하여 기존 세균에서 밝혀진 bacteria type의 phytoene desaturase의 아미노산 서열을 확보한 후, 아미노산 서열을 비교 분석하여 상동성을 조사하였다. 아미노산의 multiple sequence alignment는 Clustal W 프로그램을 사용하였으며, 계

Table 1. Primers used in this study

\begin{tabular}{|c|c|c|}
\hline Primers & Nucleotide sequences & Remark \\
\hline CE-F & 5'AGCTAW(A/T)TGCATGCCK(G/T)CCC-3' & Degenerate primer \\
\hline CE-R & 5'-TCGGS(G/C)CGTCCTGCAM(A/C)CCC-3' & Degenerate primer \\
\hline${ }_{\mathrm{Kg}} \mathrm{CrtE}-\mathrm{F} 1$ & 5'-AAGAACTGGACGCCTACTTCGA-3' & \\
\hline $\mathrm{Kg} C r t E-F 2$ & 5'-AAGACCGCCACCTACTCGTTCG-3' & Target gene cloning forward primer \\
\hline${ }_{\mathrm{Kg}} \mathrm{CrtE}-\mathrm{F} 3$ & 5'-TGGCCGATGCACAGGACGCACT-3' & \\
\hline $\mathrm{Kg}_{\mathrm{g}} \mathrm{CrtE}-\mathrm{R} 1$ & 5'-TCGAAGTAGGCGTCCAGTTCTT-3' & \\
\hline${ }_{\mathrm{Kg}} \mathrm{CrtE}-\mathrm{R} 2$ & 5'-ACAACACGTCGTCCAACTCACC-3' & Target gene cloning reverse primer \\
\hline $\mathrm{Kg} C r t E-R 3$ & 5'-CGCTCGAGTGCGTCCTGTGCAT-3' & \\
\hline${ }_{\mathrm{Kg}} \mathrm{CrtE}-\mathrm{EN}$ & 5'-CATATGATGAACTCTCCACGG-3' & $\mathrm{Kg}_{\mathrm{g}} \mathrm{CrtE}$ expression (Nde I) \\
\hline $\mathrm{Kg}_{g} \mathrm{CrtE}-\mathrm{EH}$ & 5'-AAGCTTCTTCCTCCGATGCAGC-3' & ${ }_{\mathrm{Kg}} \mathrm{CrtE}$ expression (Hind III) \\
\hline
\end{tabular}


통수(phylogenetic tree) 분석을 위해서는 neighbor-joining method를 이용하는 프로그램인 NEIGHBOR (Mega, version 4.0 )를 사용하여 작성하였다[14].

대장균 발현 벡터의 구축 및 라이코펜 생합성을 위한 재조 합 DNA 구축

확보된 $c t t E$ 유전자를 대장균에서 과발현시키기 위해서 pColdI vector (Takara, Shiga, Japan)의 Nde I과 Hind III site를 이용하여 $c r t E$ 유전자를 클로닝 하였다. 이를 위해서 T-vector 에 클로닝 된 $c r t E$ 유전자의 5'- 말단과 $3^{\prime}$-말단에 각각 $N d e$ I과 Hind III site를 가지는 primer (Table 1)를 이용하여 PCR로 증폭하였다. PCR product 및 pColdI vector를 NdeI과 Hind III 제한효소로 처리한 후 대장균 발현벡터에 클로닝하여 $\mathrm{pCcrtE}$ 재조합 DNA를 구축하였으며, 이를 대장균 BL21 (DE3)에 도입하여 형질전환된 균주를 선별하였다. 선별된 균 주는 ampicillin $50 \mathrm{\mu g} / \mathrm{ml}$ 가 함유된 LB 배지에 O.D. $600=0.5$ 일 때까지 $37^{\circ} \mathrm{C}$ 에서 배양한 후, $0.1 \mathrm{mM}$ IPTG (isopropyl- $\beta$ -thiogalactopyranoside)를 첨가하여 $16^{\circ} \mathrm{C}$ 에서 과발현을 유도 하였고, $12 \%$ sodium dodecyl sulfate polyacrylamide gel electrophoresis (SDS-PAGE)를 이용하여 분석하였다. 재조합 단 백질의 대장균 내 발현 유무 확인을 위하여 Western blot 분석 법 이용하였으며, $12 \%$ SDS-PAGE gel에 의해 분리된 C-말단 부위에 6X-histidine tag을 가진 재조합 단백질을 electrotransfer을 이용하여 nitrocellulose $(\mathrm{NC})$ membrane로 이동 시 켰으며, 이들 재조합 단백질의 확인을 위해 1 차 항체는 goat antiserum against 6-His tag를 사용하였으며, 2차 항체는 alkaline phosphate가 결합된 goat antibody against goat IgG 항체를 사용하였다. 또한, 이들 항체의 결합에 의한 NC membrane 상에서의 발색을 위한 시약은 BCIP/NBT (SigmaAldrich, St. Louis, MO, USA) 시약을 사용하여 대장균 내 재 조합 단백질인 $\mathrm{KgCrtE}$ 의 발현 유무를 확인하였다[18]. 또한, 대장균 BL21 (DE3)에서 라이코펜(lycopene) 생합성을 위해 $P$. haeundaensis의 CrtB (Phytoene synthase), CrtI (Phytoene desaturase) 유전자를 대장균 동시 발현벡터인 pRSFDuet1 vector (Novagen, Quincy, MA, U.S.A.)에 클로닝하여 pRScrtBI 재조합 DNA를 구축하였다. 이를 대장균 BL21 (DE3)에 형질 전환하여 선별하였다. 대장균에서 라이코펜을 생합성 하기 위 해서 위의 두 재조합 DNA (pCcrtE와 pRSCrtBI)를 BL21 (DE3)에 공발현(co-expression)시켜 $16^{\circ} \mathrm{C}$ 및 $37^{\circ} \mathrm{C}$ 에서 24 시간 배양하여 라이코펜 생합성을 유도하였다.

\section{대장균에서 생합성 된 라이코펜의 추출 및 분석}

대장균에서 생합성된 라이코펜은 HPLC를 사용하여 분석 하였다. 형질전환된 대장균 균주에서 색소를 추출하기 위하여 $90 \%$ acetone으로 3 분간 homogenizer 하여 색소를 추출하고, $13,000 \mathrm{rpm}$ 로 2 분간 원심분리하여, 상층액만 주사기 필터

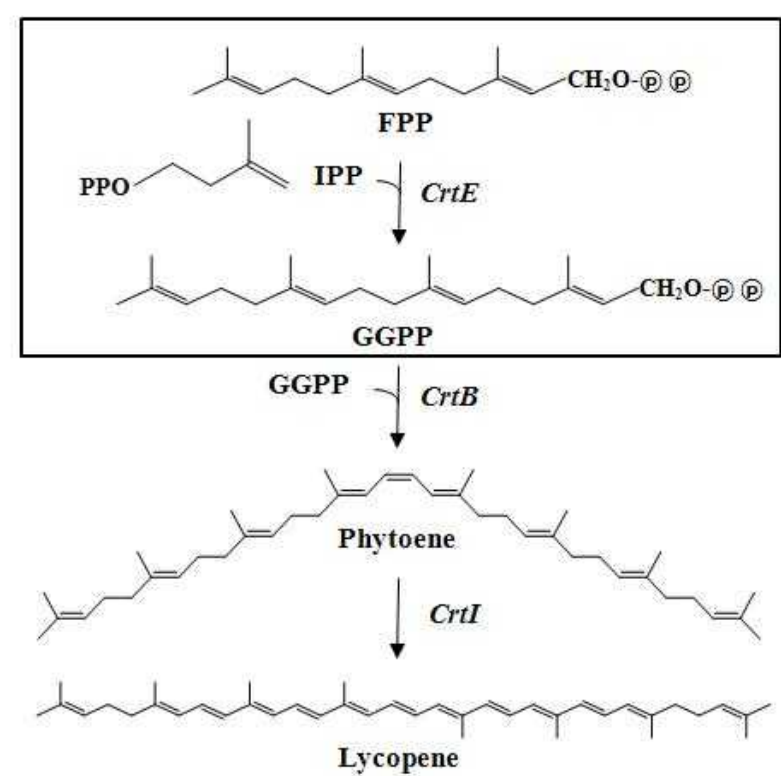

Fig. 1. Summary of lycopene biosynthetic pathway. Abbreviations used: FPP, farnesyl pyrophosphate ; IPP, isopentenyl pyrophosphate (diphosphate); CrtE, GGPP synthase; GGPP, geranlygeranyl pyrophosphate; CrtB, Phytoene synthase; CrtI, Phytoene desaturase.

(0.22 $\mu \mathrm{m}$ nylon filter)를 이용해 여과하였다. HPLC 분석을 위하여 $20 \mu \mathrm{l}$ 의 샘플을 주입하고 분리시간은 30 분 동안 진행하 였다. HPLC는 Bio-rad (Hercules, CA, U.S.A.) 사의 Automated Biologic HR system (\#750-0047)를 이용하였다. Column은 Nova-Pak HR 6 U C18 column $(3.9 \times 300 \mathrm{~mm})$ 을 사용하였고 column 온도는 $40^{\circ} \mathrm{C}$ 이다. 색소 추출을 위한 용매 는 $0.1 \mathrm{M}$ Tris- $\mathrm{HCl}$ (pH 8.0), acetonitrile, methanol, ethyl acetate가 이용되었다. HPLC 작동 중 용매의 농도는 다음과 같다: 14\% 0.1 M Tris- $\mathrm{HCl}$ (pH 8.0), 84\% acetonitrile, 2\% methanol (0-15 $\mathrm{min}), 68 \%$ methanol과 32\% ethyl acetate (15-20 $\mathrm{min})$. Post-running은 10 분간 이루어졌으며 사용된 용매의 농도는 시작할 때의 용매 농도와 같다. 컬럼 내의 유속은 분당 $1 \mathrm{ml}$ 이 되게 하였다[17]. 분리된 각각의 카로티노이드들은 photodiode array detector를 이용하여 absorption maxima인 280 $\mathrm{nm}$ 와 $470 \mathrm{~nm}$ 에서 측정하여 표준물질과 비교 분석하였으며, 라이코펜 및 GGPP standard는 Sigma-Aldrich (St. Louis, $\mathrm{MO}, \mathrm{USA})$ 에서 구입하였다.

\section{결과 및 고찰}

\section{K. gwangalliensis GGPP synthase (crte) 유전자 클 로닝}

$K$ gwangalliensis로부터 분리한 genomic DNA를 이용, cosmid genomic library를 제작하였으며 분리한 genomic DNA 와 cosmid genomic library를 주형으로 사용하여 PCR을 수행 
하였다. 또한 GGPP synthase ( $c r t E)$ 클로닝을 위한 oligonucleotide 제작은 이미 밝혀진 다양한 세균 GGPP synthase의 염기서열을 비교 분석하여 conserved domain에서 degenerate primer을 제작하였다(Table 1). 이들을 기반으로 하여 PCR 을 수행한 결과 약 $600 \mathrm{bp}$ 정도의 부분 염기서열을 얻을 수 있었다. 이렇게 밝혀진 부분 염기서열을 토대로 target specific primer를 디자인하여(Table 1), DNA walking kit 을 이용하여 약 $1.3 \mathrm{kbp}$ 정도의 PCR product를 증폭하였고, 이를 TA 클로 닝 한 후 유전자 염기서열 분석기를 이용하여 $K$ gwangalliensis GGPP synthase (KgcrtE) 유전자의 서열을 밝혔다(Fig. 2). 클 로닝된 $\mathrm{KgcrtE}$ 의 $\mathrm{ORF}$ 는 $1,158 \mathrm{bp}$, 총 386 개의 아미노산으로 구성되어 있으며 1,159-1,161 bp에 종결 코돈인 TAA 서열이 존재하고 있었다. 개시 코돈을 결정하기 위하여 ShineDalgarno 서열과 Morran 등[13]에 의해 밝혀진 그람 양성 세 균에서의 ribosome binding site를 검색하였다. 그 결과 원핵
생물에서 공통적으로 나타나는 AGGA 서열이 개시 코돈 상단 $6 \mathrm{bp}$ 에 존재하고 있었다. 또한, $\mathrm{KgcrtE}$ 에 의해 발현되는 GGPP synthase의 예상 분자량(M.W.) 및 등전점(pI)은 각각 $41.0 \mathrm{kDa}$ 과 약산성의 5.73 을 가지는 것으로 분석되었다.

\section{GGPP synthase (KgcrtE)의 아미노산 서열 분석}

$\mathrm{KgCrtE}$ 의 아미노산 서열을 토대로 예상되어지는 단백질 의 2차 구조는 SABLE website (http://sable.cchmc.org)를 활 용, transmembrane domain의 검색은 TMpred (Prediction of Transmembrane Regions and Orientation) algorithm (http://www.ch.embnet.org)을 사용하여 분석하였다. $\mathrm{KgCrtE}$ 단백질의 2 차 구조는 1 개의 $\beta$-sheet, 17 개의 a-helix 및 18 개의 random coil로 구성되어 있었다(Fig. 2). Transmembrane domain은 3 부분이 존재하는 것으로 분석되었으며, transmembrane domain의 위치는 N-terminus를 inside로 하여

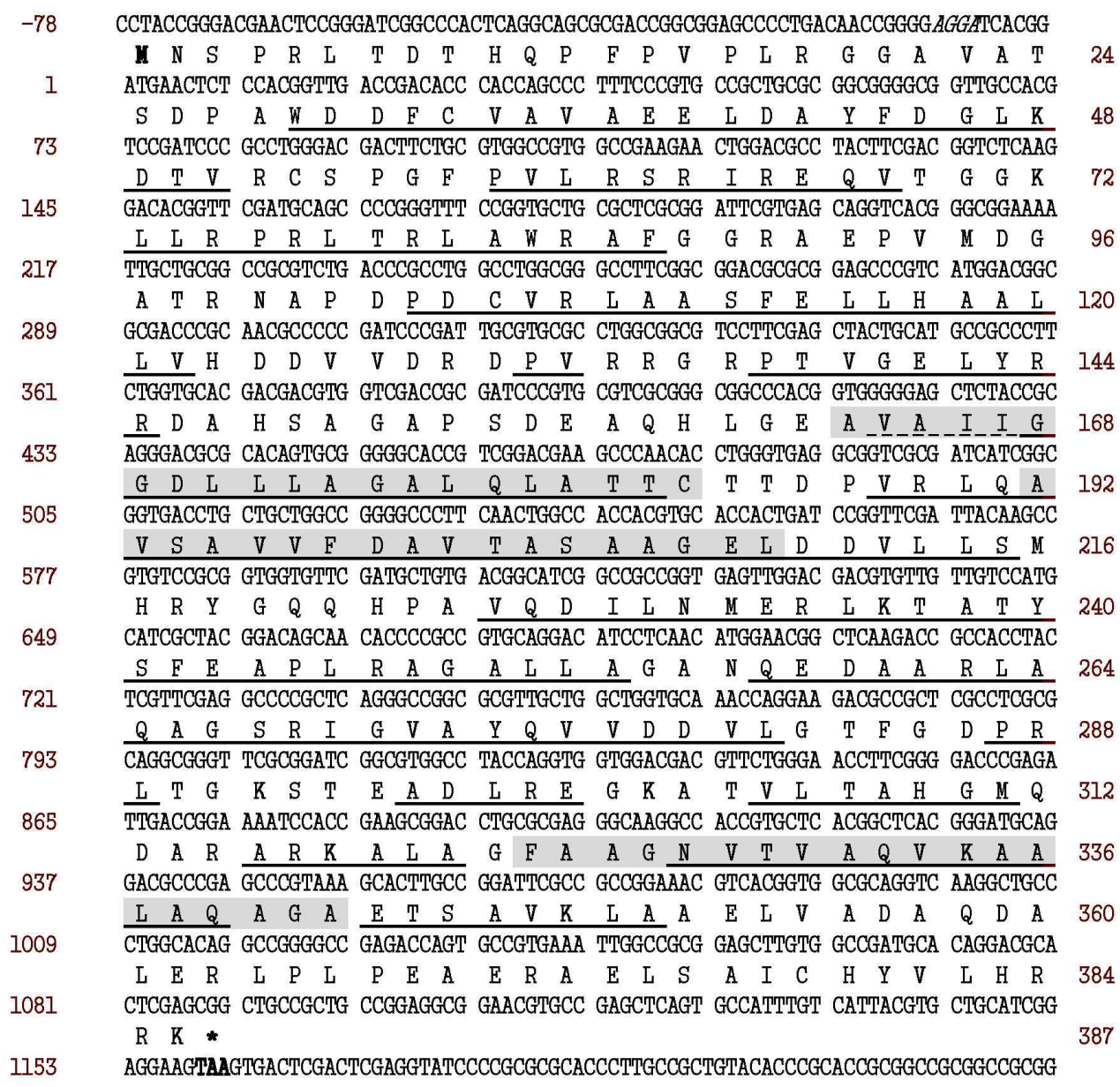

Fig. 2. Nucleotide and deduced amino acid sequence of the Kocuria gwangalliensis CrtE. The nucleotide sequence is numbered to the left and the amino acid to the right. The bold type indicates the initiator codon. The asterisk and bold type indicate the stop codon. The putative Shine-Dalgano (SD) sequences for ribosome-binding site are italic and bold type. The putative helical, beta-sheet and transmembrane regions are dash-line, underline and shadow box. The nucleotide sequence has accession number JN582050 in the GenBank database. 
163-183 아미노산, 192-209 아미노산, 323-342 아미노산 위치에 서 transmembrane helices가 존재하는 것으로 추정되었다 (Fig. 3).

$\mathrm{KgCrtE}$ 의 보존된 영역과 계통학적 유연관계를 밝히기 위 하여 GenBank에 등록된 기존 세균에서 밝혀진 GGPP synthase의 아미노산 서열을 대상으로 multiple alignment를 작 성하였다(Fig. 4). 또한, 작성된 multiple alignment를 바탕으 로 $\mathrm{KgCrtE}$ 의 계통학적 유연관계를 알아보기 위하여 phylogenetic tree 분석을 하여 Fig. 5에 나타내었다. Protein blast (BLASTP) 분석 결과, GGPP synthase는 테르페노이드 생합성 에 있어서 중요한 분지점 효소이며 단빽질 prenylation 뿐만 아니라 diterpenes 생합성에 작용하는 효소로서[5], 공통적으 로 두 개의 아스파르트산이 풍부한 영역 $[\mathrm{DDXX}(\mathrm{XX}) \mathrm{D}]$ 이 존재 하는 것으로 알려져 있고[7,19], 이들 두 부분의 아스파르트산 이 풍부한 지역이 allylic 기질과 isopentenyl diphosphate (IPP)의 결합 자리로 작용하는 것으로 알려져 있다[6]. 본 연구 에 밝혀진 $\mathrm{KgCrtE}$ 의 multiple alignment 분석에서 살펴보면 5군데의 conserved region을 찾을 수 있었으며 Fig. 4에 Domain I-V로 표시하였다. Domain II와 V는 아스파트산이 풍부한 부분으로써 motif를 포함하고 있었다. Domain II의 motif인 DDvvD는 세균 GGPP synthase에서 확인 가능하였 고, 이들의 기능은 기질의 결합에 관여하는 것으로 여겨지며, Domain $\mathrm{V}$ 에 존재하는 $\mathrm{DD}(\mathrm{XX})_{6} \mathrm{D}$ motif는 Ashby et al. [10]에 의해 밝혀진 allyl isoprenoid binding site로 추정된다. 두 영역 의 motif는 촉매 활성에 중요한 역할을 담당하는 것으로 여겨 진다.

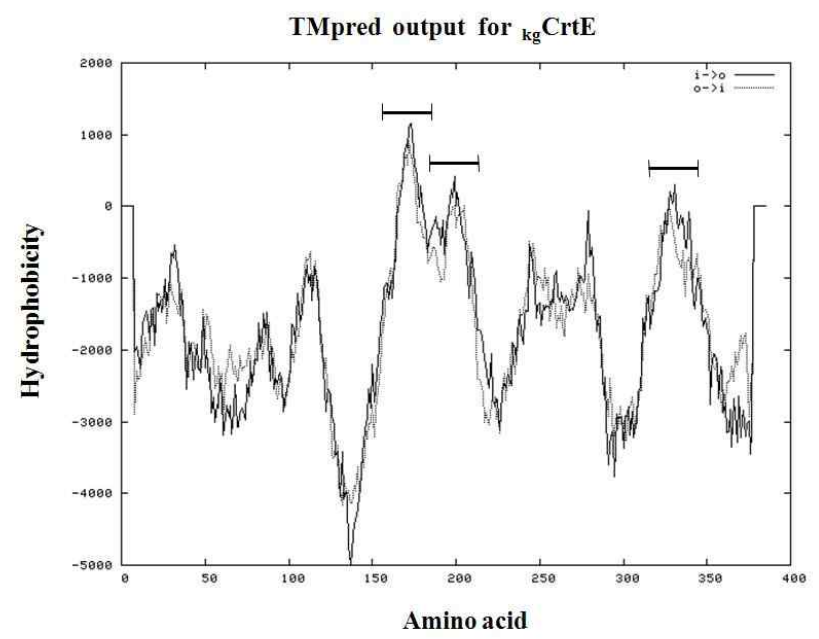

Fig. 3. Predicted hydropathy profiles for the deduced amino acid sequence of $\mathrm{KgCrtE}$ of $K$ gwangalliensis. Potential transmembrane regions are marked with a horizontal line above the profiles. Transmembrane domains of KgCrtE located in 163-183, 192-209, and 323-342 amino acids.
$\mathrm{KgCrtE}$ 의 계통학적 유연 관계를 밝히기 위하여 bacteria-type의 GGPP synthase의 아미노산 서열을 multiple alignment 분석한 결과 Kocuria rhizophila (59\%, accession no. NC010617), Micrococcus luteus (15\%, accession no. ZP06502819), Arthrobacter arilaitensis (38\%, accession no. YP003916548), Clavibacter michiganensis (46\%, accession no. YP001711260), Sanguibacter keddieii (39\%, accession no. YP003314051), Agromyces mediolanus (30\%, accession no. AAM94362), Beutenbergia cavernae (32\%, accession no. YP002880993), Brevibacterium linens (35\%, accession no. ZP05914711), Corynebacterium efficiens (25\%, accession no. NP737253), Paracoccus haeundansis (33\%, accession no. AY957386)로 밝혀졌다. 이들 서열 중 상동성이 가장 높은 것 은 같은 속(Genus)에 속하는 $K$ rhizophila의 GGPP synthase였 으며, 가장 낮은 것은 Micrococcus luteus가 생합성하는 GGPP synthase로 밝혀졌다.

\section{대장균에서 GGPP synthase (KgCrtE)의 발현과 확인}

대장균에서 $\mathrm{KgGGPP}$ synthase의 발현 유무를 확인 위하여 pColdI vector 의 NdeI/Hind III site에 $\mathrm{Kg} c r t E$ 유전자를 클로 닝 하였으며, 이를 위해 N-말단과 C-말단에 Nde I/Hind III site를 가지는 primer를 제작(Table 1)하여 $\mathrm{Kgcrt} E$ 유전자를 $\mathrm{PCR}$ 로 증폭한 후 제한효소를 처리하여 pColdI vector에 subcloning하여 재조합 $\mathrm{DNA}$ 구축하고, 이를 $\mathrm{pCCrtE}$ 로 명명하였 다(Fig. 6A). 그리고, 대장균에서 라이코펜의 생합성을 유도하 기 위하여 대장균 동시 발현벡터인 pRSFDuet-1 vector의 multiple cloning site (MCS) 1 과 MCS2에 각각 P. haeundaensis의 CrtB (Phytoene synthase), CrtI (phytoene desaturase) 유전자 를 클로닝 하였다. MCS1에 CrtB 유전자를 삽입하기 위해서 $\mathrm{N}$-말단과 C-말단에 각각 $E c o R$ I과 Not I 제한효소 자리를 $\mathrm{MCS} 2$ 에는 $\mathrm{CrtI}$ 유전자를 삽입하기 위해서 $\mathrm{N}$-말단과 C-말단 에 각각 $N d d$ 과 $X h d$ 제한효소 자리를 이용하여 재조합 DNA, pRSCrtBI를 구축하였다(Fig. 6B).

대장균에서 $\mathrm{KgcrtE}$ 유전자의 발현을 위해 $\mathrm{pCCrtE}$ 재조합 $\mathrm{DNA}$ 를 대장균 $\mathrm{BL} 21$ (DE3)에 형질전환 하였으며, 선별된 균 주를 암피실린(ampicillin) $50 \mu \mathrm{g} / \mathrm{ml}$ 가 함유된 LB 배지에 O.D. $600=0.5$ 일 때까지 $37^{\circ} \mathrm{C}$ 에서 교반 배양한 후, $\mathrm{IPTG}$ 최종 농도 $0.1 \mathrm{mM}$ 을 첨가한 후 $16^{\circ} \mathrm{C}$ 에서 교반배양 하여 과발현을 유도하였고, $12 \%$ SDS-PAGE에서 단백질 발현 패턴을 분석하 였다. 대장균 BL21 (DE3)에서 발현되는 KgGGPP synthase의 최적 발현시간은 IPTG 첨가 후 약 17 시간 정도였으며, 이들의 분자량은 앞서 아미노산 서열로 예측 분석한 약 $41 \mathrm{kDa}$ 과 일 치하였다(Fig. 7A). 또한, 대장균 BL21 (DE3)에서 과발현된 $\mathrm{KgGGPP}$ synthase는 Western blot 분석법을 이용하여 검증 확인하였으며 이를 Fig. 7B에 나타내었다. 
공발현 시스템을 통해대장균에서생산된 카로티노이드의 추출 및 분석

대장균 $\mathrm{BL} 21$ (DE3)에서 발현된 $\mathrm{KgCrtE}$ 효소의 활성을 검
증 위하여, 먼저 대장균에서의 라이코펜 생합성 유무를 확인 하였다. 대장균의 경우 메발론산 경로를 통하여 $\mathrm{FPP}$ 와 IPP를 생합성 하지만 $c r t E, c r t B, c r t I$ 유전자가 없기 때문에 라이코펜

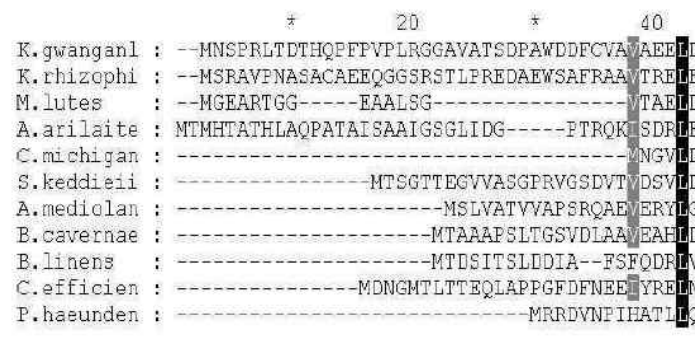

K. gwanganl : RAFGGRAEPVID- 100 K. rhizophi : RSETAPAG----GAVPSVP DAQCVRIAAS

M. Lutes : R--LATAD-

A. arilaite: RAEGGGNE

C.michigan : DGLGGQ-

S.keddieli : DDLGGT--.-.--DVAAAH G.

B. cavernae : HGLRDDAGPG-----HEEGDPDGGAAVOVA

B.linens : RGLGGR-...........-DQAAAVDAAC

C.efficien : RTMTADATAG---.-----TANREAAIOUAV

P.haeunden : EASGGVCD--.--..----TIVDAAC

\section{(1)}

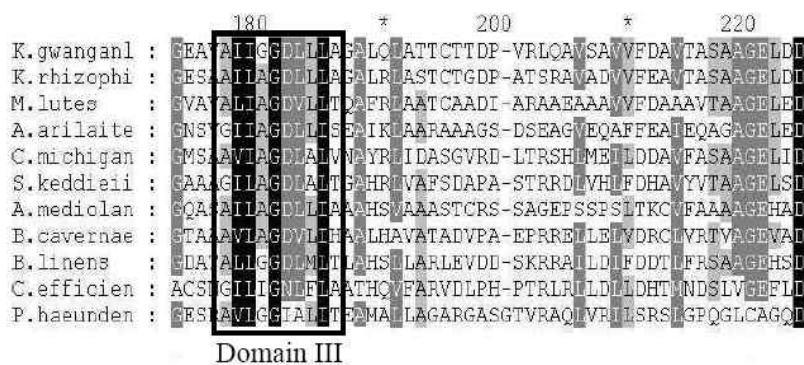

Domain III

K.guanganl :
K.rhizophi :
M. lutes :
A.arilaite :
C.michigan :
S.keddieii :
A. mediolan :
B. cavernae :
B. linens :
C.efficien :
P.haeunden :

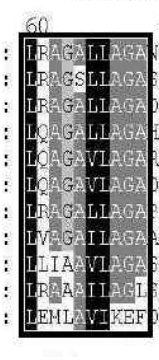

280

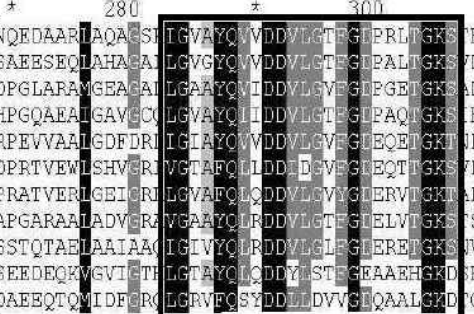

Domain V
60

LDAYFDGLIKDT-VACSP GFPVIRSAIREQ EEFFAAPTHR-VPRSP GFPVLWERTAQQ A.ALPHAAAO-AP GSAAFAELILS LHVH IAIQAQRRSAAYSAQTALWWSISKS DFFA.EAI DRSDAYGSDYT QIWTS LQSA GGEFDDAIVRADAHAADYRRIWAARRDAZ DGALAERAALTS DGGAAVGSWWRAVREAC VOVLT DARHR SRGVSAO 7 GOINDS LTHMA WRT FSS ISNRCSGYGP EFRAC LDTAFQA
OTRLIEIAQGEGAVSOP IGAAMS--HGA

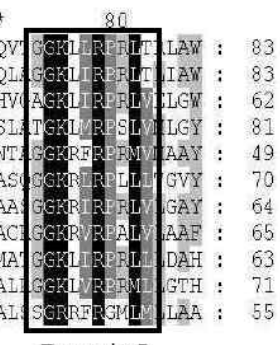

Domain I

160

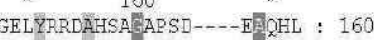
GELFRDDAAAAGAPAH---EAEHA : 156 HASARHRLEAR GVPAA----DAAHA： 132 SALYRDOASASERSLA----DMEHA : 146

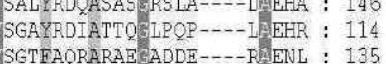
SGTEAQRARAE ADDE----PMEINL : 135 AGRFA.LDAALPGIERE---DPADAY : 144 IAELAEAAHT DGVGSS---P PHEW : 140

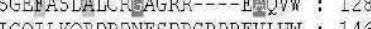
IGQILKORDPDNF SDRGPDPEHLFW : 146

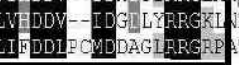
HVAH : 104

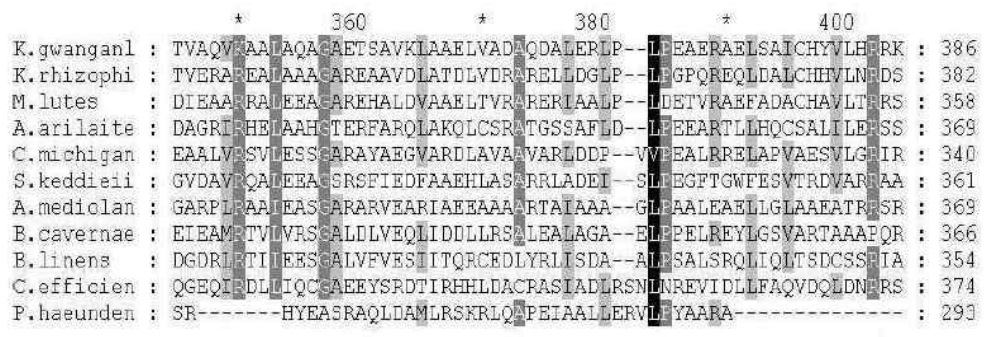

Fig. 4. Multiple alignment of deduced amino acid sequences of $\mathrm{KgCrtE}$ and other bacteria. The amino acid sequences are obtained from GeneBank: kocuria rhizophila (NC010617), Micrococcus lutes (ZP06502819), Arthrobacter arilaitensis (YP003916548), Clavibacter michiganensis (YP001711260), Sanguibacter keddieii (YP003314051), Agromyces mediolanus (AAM94362), Beutenbergia cavernae (YP002880993), Brevibacterium linens (ZP05914711), Corynebacterium efficiens (NP737253), Paracoccus haeundansis (AY957386), Kocuria gwangalliensis (JN582050) 


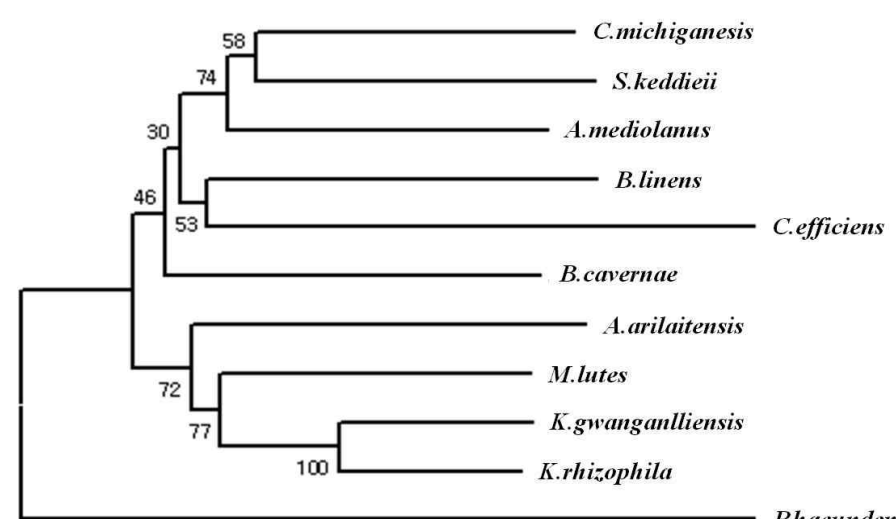

Phaeundensis

Fig. 5. A molecular phylogenetic tree of CrtI based on the NJ method. Numbers at nodes indicate levels of bootstrap support based on 1,000 replicated datasets. Bar, 0.1 substitutions per amino acids position.

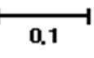

A

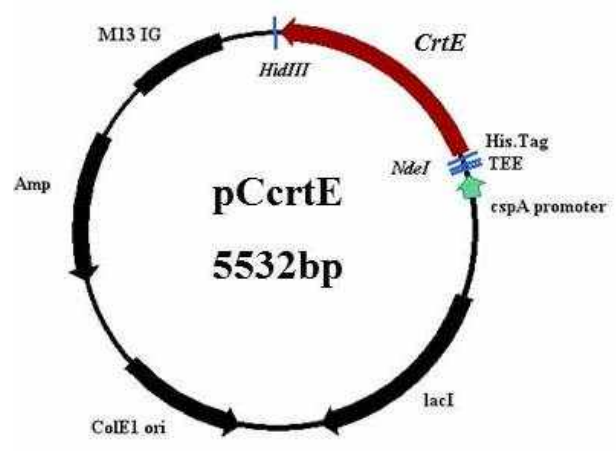

B

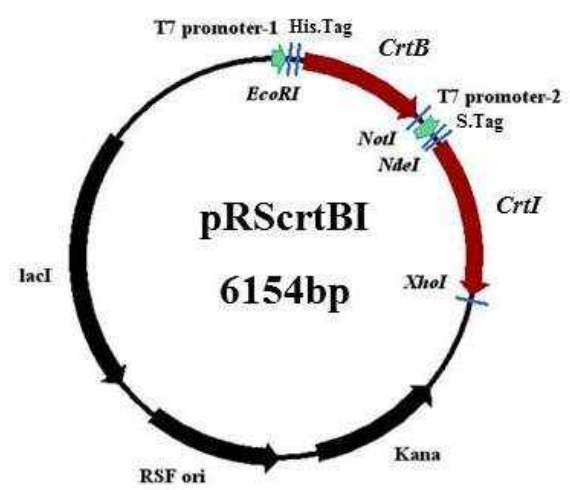

Fig. 6. Constructions of the lycopene biosynthesis gene expression plasmid. (A) The pCcrtE plasmid carried the geranlygeranyl pyrophosphate biosynthesis gene $(\mathrm{KgCrtE})$ of $K$ gwangalliensis. (B) pRScrtBI carried the lycopene biosynthesis gene cluster composed of two structural genes ( $c r t B$ and $c r t)$ of $P$. haeundaensis.

A

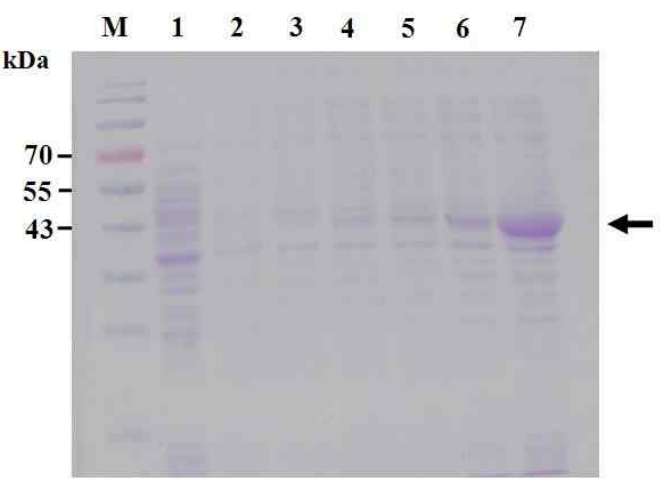

B

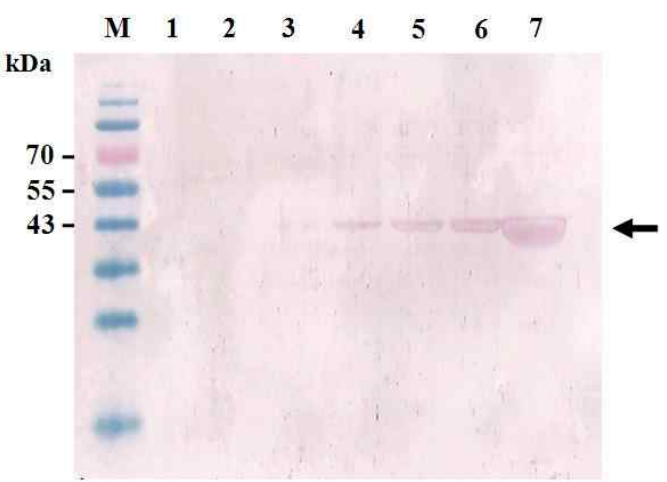

Fig. 7. Analysis of KgGGPP synthase (CrtE) by SDS-PAGE and Western blotting. Lane M, standard protein molecular weight markers; Lane 1, uninduced cell extracts as control; lanes 2-7, induced cell extracts 0, 1, 3, 5, 7, and $17 \mathrm{hr}$ after IPTG induction, respectively. (A) The expressed proteins were resolved by 12\% SDS-PAGE. (B) Western blot analysis of the expressed proteins. Proteins were electrotransferred from the SDS-PAGE gel to a nitrocellulose membrane, probed with goat antiserum against 6-His tag, and incubated with alkaline phosphatase coupled goat antibody against goat IgG. The nitrocellulose membrane was developed using the BCIP/NBT. 


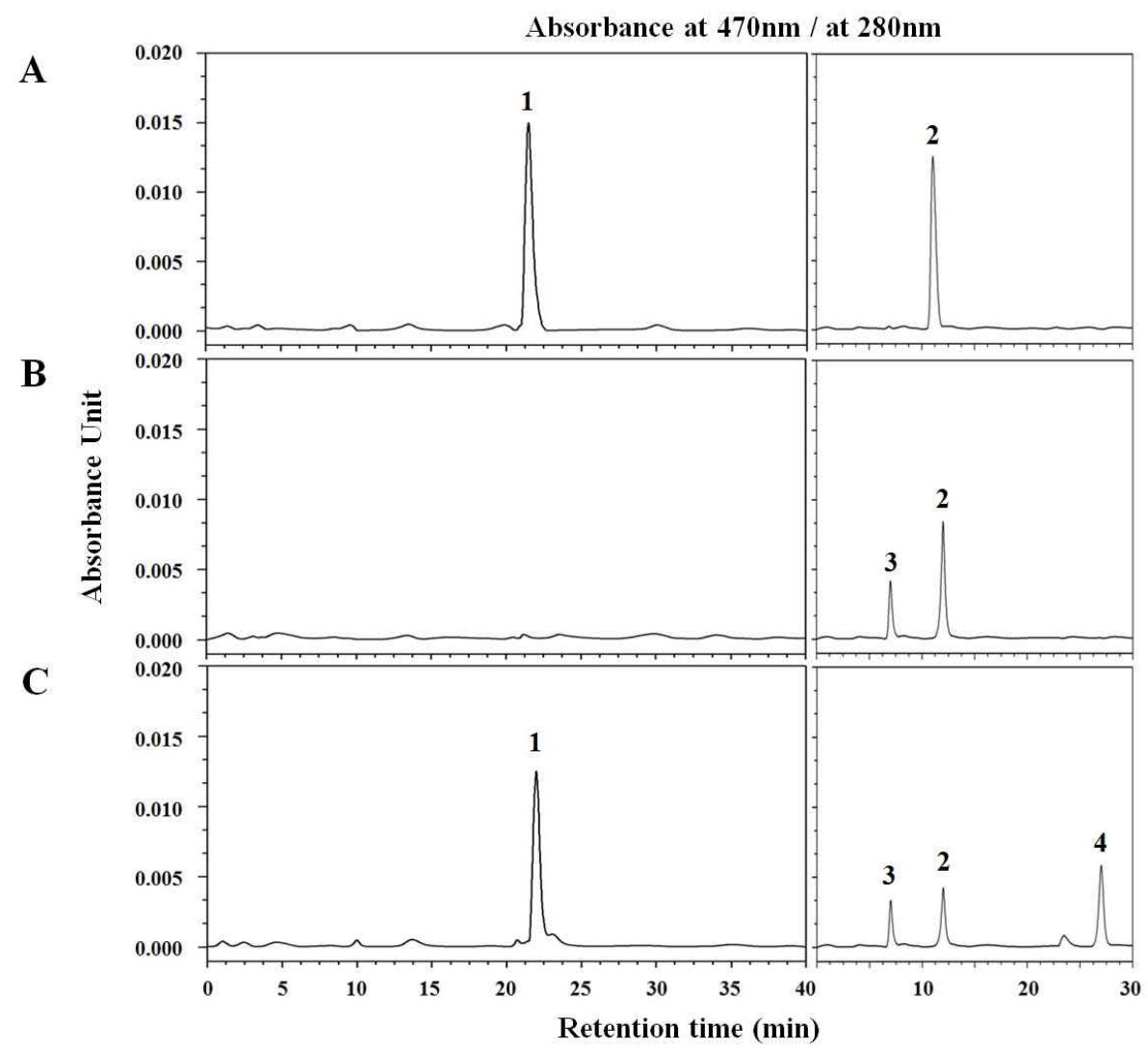

Fig. 8. HPLC analysis of carotenoids expressed in E. coli. Carotenoids are detected at absorbance $280 \mathrm{~nm}$ and $470 \mathrm{~nm}$. (A) Lycopene and GGPP standard. (B) E. coli containing plasmid pCcrtE. (C) E. coli containing pCcrtE and pRScrtBI. Peak 1, lycopene; Peak 2, GGPP; Peak 3, putative FPP or IPP; Peak 4, phytoene.

을 생합성 하지는 못한다. 이러한 특징을 이용하여 대장균 BL21 (DE3)에 앞서 구축된 두 재조합 DNA을 형질전환 시켜 이들을 공발현 시켰다. 그리고 형질전환된 균주에서 생산되는 라이코펜은 실험 방법에서 서술한 것처럼 추출하여 HPLC 분 석법을 이용하여 생합성 유무를 확인하였다. 카로티노이드는 종류에 따라 각각의 서로 다른 최대 흡수(absorption maxima) 파장대를 가지고 있다. 파이토엔(Phytoene) 등의 absorption maxima는 $280 \mathrm{~nm}$ 이며, 라이코펜의 경우 absorption maxima 는 $470 \mathrm{~nm}$ 로 알려져 있다[24]. 본 연구에서 생산된 이들 카로 티노이드는 표준물질과 더불어 HPLC 분석을 통하여 각각의 absorption maxima인 $280 \mathrm{~nm}$ 와 $470 \mathrm{~nm}$ 에서 측정하였으며, 분석된 결과는 Fig. 8 에 나타냈었다. Fig. $8 \mathrm{~A}$ 는 표준물질 라이 코펜과 GGPP이며, 라이코펜의 경우 absorption $470 \mathrm{~nm}$ 에서 retention time 22 분(peak 1)에서 분리되었으며, GGPP는 absorption $280 \mathrm{~nm}$, retention time 13 분(peak 2)에서 분리되어 짐을 확인할 수 있다. Fig. $8 \mathrm{~B}$ 는 $\mathrm{pCCr}$ 트 재조합 $\mathrm{DNA}$ 가 형질전 환된 대장균에서 생산된 추출물을 HPLC로 분석한 결과로서, 표준물질을 활용한 분석 결과(Fig. $8 \mathrm{~A})$ 와 비교하였을 때 동일 한 시간대의 retention time에서 GGPP가 생산됨을 확인 할
수 있다. 또한 peak 3 (retention time 8 분)의 경우 대장균에서 생산되는 FPP 또는 IPP로 추정되며, 본 연구에서는 대장균에 서 생산되는 카로티노이드를 중점으로 연구하였기 때문에 따 로 이들을 비교 분석하지는 않았다. 마지막으로 Fig. $8 \mathrm{C}$ 의 결 과는 $\mathrm{pCrtE}$ 와 $\mathrm{pRSCrtBI}$ 재조합 DNA를 공발현 시켜 생산된 카로티노이드계 물질을 추출하여 HPLC 분석을 실시한 결과 로서, 표준물질의 분석 결과와 비교한 결과 absorption 470 $\mathrm{nm}$ 에서 retention time 22 분대에서 라이코펜이 생산됨을 확 인 할 수 있었고 absorption $280 \mathrm{~nm}$, retention time 8 분(peak 3), 13 분(peak 2), 27 분(peak 4)에서 각각 FPP (or IPP), GGPP, Phytoene이 생산됨을 확인 할 수 있었다. 이상의 결과들을 종 합하여 추론하면, 대장균 형질전환체에서 생합성된 $\mathrm{KgCrtE}$ 는 그 효소적 특성을 잃지 않고 정상적으로 기능을 수행하고 있 음을 확인할 수 있었다.

본 연구에서는 $K$ gwangalliensis로부터 카로티노이드 생합 성 경로의 첫 번째 물질을 생합성하는 GGPP synthase를 암호 화 하는 $c t t E$ 의 클로닝과 $\mathrm{KgCrtE}$ 단백질의 1,2 차 구조 분석을 통한 이 효소의 구조적 특징을 분석, 효소활성의 검증을 위해 BL21 (DE3)에서 GGPP 및 라이코펜 의 생합성을 유도하여 
$\mathrm{CrtE}$ 의 기능적 활성 유무를 HPLC 분석법을 통해 표준물질과 비교 검증하였다. 따라서, 본 연구의 결과는 새로운 카로티노 이드 생합성 유전자의 발굴과 비카로티노이드 생합성 균주에 서의 다양한 카로티노이드 생산을 위한 기초 데이터로 이용될 수 있을 것으로 사료된다.

\section{감사의 글}

이 논문은 2008년 정부재원(교육인적자원부 학술연구조성 사업비)으로 한국학술진홍재단의 지원을 받아 연구되었음 (KRF-2008-359-F00012).

\section{References}

1. Amar, Y., Kiron, V., Satoh, S. and Watanabe, T. 2004. Enhancement of innate immunity in rainbow trout (Oncorhynchus mykiss Walbaum) associated with dietary intake of carotenoids from natural products. Fish Shellfish Immunol. 16, 527-537.

2. Breitenbach, J., Visser, H., Verdoes, J. C., van Ooyen, A. J. and Sandmann, G. 2011. Engineering of geranylgeranyl pyrophosphate synthase levels and physiological conditions for enhanced carotenoid and astaxanthin synthesis in Xanthophyllomyces dendrorhous. Biotechnol. Lett. 33, 755-761.

3. Chemler, J. A., Yan, Y. and Koffas, M. A. 2006. Biosynthesis of isoprenoids, polyunsaturated fatty acids and flavonoids in Sacharomyces cerevisiae Microb. Cell Fact. 23, 5-20.

4. Christianson, D. W. 2008. Unearthing the roots of the terpenome. Curr. Opin. Chem Biol. 12, 141-150.

5. Engprasert, S., Taura, F., Kawamukai, M. and Shoyama, Y. 2004. Molecular cloning and functional expression of geranylgeranyl pyrophosphate synthase from Coleus forskohlii Briq. BMC Plant Biol. 4, 18

6. Fernandez-Garayzabal, J. F., Dominguez, L., Pascual, C., Jones, D. and Collins, M. D. 1995. Phenotypic and phylogenetic characterization of some unknown coryneform bacteria isolated from bovine blood and milk: description of Sanguibacter gen. nov. Lett. Appl. Microbiol. 20, 69-75.

7. Hemmi, H., Noike, M., Nakayama, T. and Nishino, T. 2003. An alternative mechanism of product chain-length determination in type III geranylgeranyl diphosphate synthase. Biochem 270, 2186-2194.

8. Hunter, W. N. 2007 The non-mevalonate pathway of isoprenoid precursor biosynthesis. J. Biol. Chem 282, 21573-21577.

9. Irlinger, F., Bimet, F., Delettre, J., Lefevre, M. and Grimont, P. A. D. 2005. Arthrobacter bergerei sp. nov. and Arthrobacter arilaitensis $s p$. nov. novel coryneform species isolated from the surfaces of cheeses. Int. J. Syst. Evol. Microbid. 55, 457 462.

10. Lin, J., Jin, Y. J., Zhou, X.,and Wang, J. Y. 2010. Molecular cloning and functional analysis of the gene encoding geranylgeranyl diphosphate synthase from Jatropha curcas.
Biotechnol. 9, 3342-3351.

11. Lee, J. H. and Kim, Y. T. 2006. Cloning and characterization of the astaxanthin biosynthesis gene cluster from the marine bacterium Paracoccus haeundaensis. Gene 370, 86-95.

12. Lee, J. H., Kim, Y. S., Choi, T. J., Lee, W. J. and Kim, Y. T. 2004. Paracoccus haeundaensis sp. nov., a Gram-negative, halophilic, astaxanthin-producing bacterium. Int. J. Syst. Evol. Microbiol. 54, 1699-1702.

13. Morran, C. P. Jr., Lang, N., Le Grice, F. J., Lee, G., Stephens, M., Sonenshein, A. L., Pero, J. and Losick, R. 1982. Nucleotide sequences that signal the initiation of transcription and translation in Bacillus subtilis. Mol. Gen. Genet. 186, 339-346.

14. Saitou, N. and Nei, M. 1987. The neighbor-joining method: A new method for reconstructing phylogenetic trees. Mol. Biol. Evol. 4, 406-425.

15. Sambrook, J. and Russell, D. W. 2001. Molecular cloning: a laboratroy manual. pp. 4.7-4.10. 3th eds. Cold Spring Harbor Laboratroy Press, Cold Spring Harbor, New York, USA.

16. Seo, Y. B., Kim, D. E., Kim, G. D., Kim, H. W., Nam, S. W., Kim, Y. T. and Lee, J. H. 2009. Kocuria gwangalliensis sp. nov., an actinobacterium isolated from seawater. Int. J. Syst. Evol. Microbiol. 59, 2769-2772.

17. Seo, Y. B., Choi, S. S., Nam, S. W., Lee, J. H. and Kim, Y. T. 2009. Cloning and characterization of the zeaxanthin glucosyltransferase Gene $(c r t X)$ from the astaxanthin-producing marine bacterium, Paracoccus haeundaensis. J. Microbiol. Biotechnol. 19, 1542-1546.

18. Seo, Y. B., Hwang H. H. and Kim, Y. T. 2011. Molecular characterization and tissue expression of carboxypeptidase $\mathrm{H}(\mathrm{CPH})$ gene in flounder (Paralichthys olivaceus). Biotechnol. Bioprocess Eng. 16, 374-382.

19. Sitthithaworn, W., Kojima, N., Viroonchatapan, E., Suh, D. Y., Iwanami, N., Hayashi, T., Noji, M. Saito, K., Niwa, Y. and Sankawa, U. 2001. Geranylgeranyl diphosphate synthase from Scoparia dulcis and Croton sublyratus. Plastid localization and conversion to a farnesyl diphosphate synthase by mutagenesis. Chem Pharm Bull. 49, 197-202.

20. Takarada, H., Sekine, M., Kosugi, H., Matsuo, Y., Fujisawa, T., Omata, S., Kishi, E., Shimizu, A., Tsukatani, N., Tanikawa, S., Fujita, N. and Harayama, S. 2008. Complete genome sequence of the soil actinomycete Kocuria rhizophila. J. Bacteriol. 190, 4139-4146.

21. Wang, K. and Ohnuma, S. 1999. Chain-length determination mechanism of isoprenyl diphosphate synthases and implications for molecular evolution. Trends Biochem Sci. 24, 445-451.

22. Young, J. M., Saddler, G. S., Takikawa, Y., De Boer, S. H., Vauterin, L., Gardan, L., Gvozdyak, R. I. and Stead, D. E. 1996. Names of plant pathogenic bacteria 1864-1995. Rev. Plant Pathol. 75, 721-763.

23. Young, M., Artsatbanov, V., Beller, H. R., Chandra, G., Chater, K. F., Dover, L. G., Goh, E. B., Kahan, T., Kaprelyants, A. S., Kyrpides, N., Lapidus, A., Lowry, S. R., Lykidis, A., Mahillon, J., Markowitz, V., Mavrommatis, K., 
Mukamolova, G. V., Oren, A., Rokem, J. S., Smith, M. C., Young, D. I. and Greenblatt, C. L. 2010. Genome sequence of the Fleming strain of Micrococcus luteus, a simple free-living actinobacterium J. Bacteriol. 192, 841-860.
24. Xu, Z., Tian, B. Sun, Z., Lin, J., and Hua, Y. 2007. Identification and functional analysis of a phytoene desaturase gene from the extremely radioresistant bacterium Deinococcus radiodurans. Microbiology 153, 1642-1652.

초록 : 코쿠리아 광안리엔시스의 제라닐제라닐 피로인산염 합성 효소의 클로닝과 대장균에서 공발현을 통한 효소 활성에 관한 연구

서용배 ${ }^{1} \cdot$ 김군도 $^{1} \cdot$ 이재형 ${ }^{2} \star$

( ${ }^{1}$ 부경대학교 미생물학과, ${ }^{2}$ 부경대학교 기초과학연구소)

Kocuria gwangalliensis로부터 카로티노이드 생합성 경로의 첫 번째 단계 기질인 geranylgeranyl pyrophosphate (GGPP)를 생합성하는 GGPP synthase (CrtE)를 암호화하고 있는 $c r t E$ 를 클로닝 하여 이를 KgGGPP로 명명하였 다. 기존 세균에서 밝혀진 GGPP synthase의 아미노산 서열을 NCBI에서 검색하여 KgGGPP synthase의 아미노산 서열과 비교한 결과 Kocuria rhizophila와 59.6\%의 상동성을 가지는 것을 확인하였다. $c r t E$ 유전자를 대장균에서 발현 시키기 위하여 $\mathrm{pCcrtE}$ 재조합 $\mathrm{DNA}$ 를 구축하였고, 이를 대장균에서 발현시킨 결과 약 $41 \mathrm{kDa}$ 의 재조합 단백질이 과발현 됨을 확인 할 수 있었으며, 이 단백질은 기존 세균에서 밝혀진 GGPP synthase와 유사한 분자량 을 가지고 있다는 것을 알 수 있었다. $\mathrm{CrtE}$ 재조합 단백질의 활성을 분석하기 위하여 대장균 내에서 라이코펜의 생합성을 유도 하였다. 대장균의 경우 메발론산 경로를 통하여 $\mathrm{FPP}$ 와 IPP를 생합성 하지만 $c r t E, c r t B, c r t I$ 유전자 가 없기 때문에 라이코펜을 생합성 하지는 못한다. 대장균 내에서 라이코펜의 생합성을 위해서는 $c r t E, c r t B, c r t I$ 유전자의 발현이 필수적으로 요구되기 때문에 $c r t B, c r t I$ 유전자의 경우는 P. haeundaensis에서 유래한 유전자를 이용하여 pRScrtBI 재조합 DNA를 구축하여 그 발현을 유도하였다. 상기 두 재조합 DNA를 대장균에서 공발현 시켰으며, HPLC 분석법을 이용하여 대장균 내에서 라이코펜의 생산 유무에 따른 KgGGPP synthase의 활성을 분석하였다. 